\section{Impacts of Atmospheric Anthropogenic Nitrogen on the Open Ocean}

R. A. Duce, ${ }^{1 *}$ ]. LaRoche, ${ }^{2}$ K. Altieri, ${ }^{3}$ K. R. Arrigo, ${ }^{4}$ A. R. Baker, ${ }^{5}$ D. G. Capone, ${ }^{6}$ S. Cornell, ${ }^{7}$ F. Dentener, ${ }^{8}$ J. Galloway, ${ }^{9}$ R. S. Ganeshram, ${ }^{10}$ R. J. Geider, ${ }^{11}$ T. Jickells, $^{5}$ M. M. Kuypers, ${ }^{12}$ R. Langlois, ${ }^{2}$ P. S. Liss, ${ }^{5}$ S. M. Liu, ${ }^{13}$ J. J. Middelburg, ${ }^{14}$ C. M. Moore, ${ }^{11}$ S. Nickovic, ${ }^{15}$ A. Oschlies, ${ }^{2}$ T. Pedersen, ${ }^{16}{ }^{2}$. Prospero, ${ }^{17}$ R. Schlitzer, ${ }^{18}$ S. Seitzinger, ${ }^{3}$ L. L. Sorensen, ${ }^{19}$ M. Uematsu, ${ }^{20}$ O. Ulloa, ${ }^{21}$ M. Voss, ${ }^{22}$ B. Ward, ${ }^{23}$ L. Zamora $^{17}$

Increasing quantities of atmospheric anthropogenic fixed nitrogen entering the open ocean could account for up to about a third of the ocean's external (nonrecycled) nitrogen supply and up to $\sim 3 \%$ of the annual new marine biological production, $\sim 0.3$ petagram of carbon per year. This input could account for the production of up to $\sim 1.6$ teragrams of nitrous oxide $\left(\mathrm{N}_{2} \mathrm{O}\right)$ per year. Although $\sim 10 \%$ of the ocean's drawdown of atmospheric anthropogenic carbon dioxide may result from this atmospheric nitrogen fertilization, leading to a decrease in radiative forcing, up to about two-thirds of this amount may be offset by the increase in $\mathrm{N}_{2} \mathrm{O}$ emissions. The effects of increasing atmospheric nitrogen deposition are expected to continue to grow in the future.

$\mathrm{N}$ itrogen is an essential nutrient in terrestrial and marine ecosystems. Most nitrogen in the atmosphere and ocean is present as $\mathrm{N}_{2}$ and is available only to diazotrophs, a restricted group of microorganisms that can fix

${ }^{1}$ Departments of Oceanography and Atmospheric Sciences, Texas A\&M University, College Station, TX 77843, USA. ${ }^{2}$ Leibniz-Institut fuer Meereswissenschaften, 24105 Kiel, Germany. ${ }^{3}$ Institute of Marine and Coastal Sciences, Rutgers University, Rutgers/NOAA CMER Program, New Brunswick, N] 08901, USA. ${ }^{4}$ Department of Environmental Earth System Science, Stanford University, Stanford, CA 94305, USA ${ }^{5}$ School of Environmental Sciences, University of East Anglia, Norwich NR4 7T], UK. ' Department of Biological Sciences, University of Southern California, Los Angeles, CA 90089, USA ${ }^{7}$ QUEST-Earth Sciences, University of Bristol, Bristol BS8 1R] UK. ${ }^{8}$ European Commission, Joint Research Centre, Institute for Environment and Sustainability, TP290, I-21020, Ispra (Va), Italy. ${ }^{9}$ Department of Environmental Sciences, University of Virginia, Charlottesville, VA 22904, USA. ${ }^{10}$ John Murray Laboratories, The King's Buildings, Edinburgh EH9 3JW, UK. ${ }^{11}$ Department of Biological Sciences, University of Essex, Colchester CO4 3SQ, UK, and National Oceanography Centre, University of Southampton, Southampton SO14 3ZH, UK.

${ }^{12}$ Max Planck Institute for Marine Microbiology, Celsiusstrasse 1, D-28359 Bremen, Germany. ${ }^{13}$ Key Laboratory of Marine Chemistry Theory and Technology Ministry of Education, College of Chemistry and Chemical Engineering, Ocean University of China, Qingdao 266100, Peoples Republic of China. ${ }^{14}$ Netherlands Institute of Ecology, Korringaweg 7, 4401 NT Yerseke, Netherlands. ${ }^{15}$ Atmospheric Research and Environment Programme, World Meteorological Organization, BP2300, 1211 Geneva 2, Switzerland. ${ }^{16}$ University of Victoria, Post Office Box 3055 STN CSC, Victoria, BC V8W 3P6, Canada

${ }^{17}$ Rosenstiel School of Marine and Atmospheric Sciences, University of Miami, Miami, FL 33149, USA. ${ }^{18}$ Alfred Wegener Institute for Polar and Marine Research, 27568 Bremerhaven, Germany. ${ }^{19}$ National Environmental Research Institute, Aarhus University, Denmark. ${ }^{20}$ Ocean Research Institute, University of Tokyo, Tokyo 164-8639, Japan. ${ }^{21}$ Departamento de Oceanografía, Centro de Investigación Oceanográfica, COPAS, and Nucleo Milenio EMBA, Universidad de Concepción, Casilla 160-C, Concepción, Chile. ${ }^{22}$ Leibnitz Institute for Baltic Sea Research, Warnemünde, 18119 Rostock, Germany. ${ }^{23}$ Department of Geosciences, Princeton University, Princeton, N] 08544, USA.

*To whom correspondence should be addressed. E-mail: rduce@ocean.tamu.edu
$\mathrm{N}_{2}$. Most organisms can only assimilate forms of reactive nitrogen (fixed nitrogen, $\mathrm{N}_{\mathrm{r}}$ ), including oxidized and reduced inorganic and organic forms. The availability of $\mathrm{N}_{\mathrm{r}}$ limits primary production, the conversion of inorganic carbon to organic carbon (1), in much of the ocean. Reactive nitrogen enters the ocean via rivers, $\mathrm{N}_{2}$ fixation, and atmospheric deposition. It is removed via $\mathrm{N}_{2}$ formation by denitrification and anaerobic ammonium oxidation (anammox), nitrous oxide $\left(\mathrm{N}_{2} \mathrm{O}\right)$ and ammonia emissions, and burial of organic matter in sediments. Human activities have severely altered many coastal ecosystems by increasing the input of anthropogenic nitrogen through rivers and groundwater, direct discharges from wastewater treatment, atmospheric deposition, and so forth, resulting in increasing eutrophication. Human activities have also added large quantities of atmospheric $\mathrm{N}_{\mathrm{r}}$ to central ocean regions.

Riverine input of $\mathrm{N}_{\mathrm{r}}$ to the oceans is estimated as 50 to $80 \mathrm{Tg} \mathrm{N}_{\text {year }}{ }^{-1}$ (2-4). However, much is either lost to the atmosphere after $\mathrm{N}_{2}$ conversion or buried in coastal sediments, never reaching oceanic regions (5). We assume that riverine $\mathrm{N}_{\mathrm{r}}$ has a negligible impact on the open ocean nitrogen inventory, and we do not consider it further. Estimates of global ocean $\mathrm{N}_{2}$ fixation range from 60 to $200 \mathrm{Tg} \mathrm{N}$ year $^{-1}(2,6-8)$. Although impacts of the amplified nitrogen inputs to terrestrial here we show that atmospheric transport and deposition is an increasingly important pathway for $\mathrm{N}_{\mathrm{r}}$ entering the open ocean, often poorly represented in analyses of open ocean anthropogenic impacts (10-16). Atmospheric $\mathrm{N}_{\mathrm{r}}$ input is rapidly approaching global oceanic estimates for $\mathrm{N}_{2}$ fixation and is predicted to increase further due to emissions from combustion of fossil fuels and production and use of fertilizers. Our objective is to highlight the growing imsystems are being continuously evaluated $(3,9)$, portance of anthropogenic atmospheric $\mathrm{N}_{\mathrm{r}}$ (AAN) deposition to the oceans and evaluate its impact on oceanic productivity and biogeochemistry.

\section{Atmospheric Emission and Deposition of Nitrogen Species}

Atmospheric emissions of $\mathrm{N}_{\mathrm{r}}$ are primarily oxidized nitrogen species, $\mathrm{NO}_{x}\left(\mathrm{NO}+\mathrm{NO}_{2}\right)$ and $\mathrm{NH}_{3}$. Recent studies suggest that atmospheric water-soluble organic nitrogen is far more abundant than conventionally thought, constituting $\sim 30 \%$ of total $\mathrm{N}_{\mathrm{r}}$ deposition $(13,17-20)$. Given the uncertain origins and complex composition of this material, the importance of direct emissions and secondary formation of organic nitrogen is unclear. However, measurements suggest that an important fraction is anthropogenic $(13,17)$. We therefore assume that in 1860 , the relationship between organic and inorganic nitrogen deposition was the same as it is today and increase our 1860 estimate so that organic nitrogen represents $30 \%$ of total $\mathrm{N}_{\mathrm{r}}$ deposition. The uncertainties associated with this assumption emphasize the need for further research on atmospheric organic nitrogen.

Estimated total $\mathrm{N}_{\mathrm{r}}$ and AAN emissions in 1860,2000 , and 2030 (Table 1) show that anthropogenic emissions have significantly increased since the mid-1800s and future increases are expected (21). Over the next 20 to 25 years, the proportion of $\mathrm{NH}_{3}$ emissions will likely increase due to enhanced atmospheric emission controls predicted to be more effective for $\mathrm{NO}_{\mathrm{x}}$ than $\mathrm{NH}_{3}$ (Table 1) (21). An important fraction of atmospheric $\mathrm{N}_{\mathrm{r}}$ emissions is deposited on the ocean (Table 1). In 1860, this amounted to $\sim 20 \mathrm{Tg} \mathrm{N}$ year $^{-1}$, of which $\sim 29 \%$ was anthropogenic. By 2000, the total $\mathrm{N}_{\mathrm{r}}$ deposition to the ocean had more than tripled to $\sim 67 \mathrm{Tg} \mathrm{N}$ year ${ }^{-1}$, with $\sim 80 \%$ being anthropogenic. This is greater than the $39 \mathrm{Tg} \mathrm{N}$ year ${ }^{-1}$ reported by (14), in part because our estimate includes water-soluble organic nitrogen. Estimates of anthropogenic emissions for 2030 indicate a $\sim$ 4-fold increase in total atmospheric $\mathrm{N}_{\mathrm{r}}$ deposition to the ocean and an $\sim 11$ fold increase in AAN deposition compared with $1860(22)$.

The spatial distribution of atmospheric deposition has also changed greatly (Fig. 1, A and B). Deposition to most of the ocean was $<50 \mathrm{mg}$ $\mathrm{N} \mathrm{m}^{-2}$ year $^{-1}$ in 1860 , with very few areas $>200 \mathrm{mg}$ $\mathrm{N} \mathrm{m}^{-2}$ year $^{-1}$. Most oceanic deposition was from natural sources; anthropogenic sources impacted only a few coastal regions. By 2000 , deposition over large ocean areas exceeded $200 \mathrm{mg} \mathrm{N} \mathrm{m}^{-2}$ year $^{-1}$, reaching $>700 \mathrm{mg} \mathrm{N} \mathrm{m}^{-2}$ year $^{-1}$ in many areas. Intense deposition plumes extend far downwind of major population centers in Asia, India, North and South America, around Europe, and west of Africa (Fig. 1B). A direct comparison of deposition in 1860 and 2000 shows almost all ocean surface areas now being affected by AAN deposition (Fig. 1, A and B). Predictions for 2030 (fig. S1) indicate similar patterns, but with 
increased deposition further into open ocean regions $(21,22)$. The ratio of 2030-to-2000 deposition rates (Fig. 1C) shows up to a factor of 2 increase in Southeast Asia, the Bay of Bengal, and the Arabian Sea; up to a 50\% increase off western Africa; and up to $30 \%$ across essentially all the mid-latitude North Atlantic and North Pacific. As Galloway et al. (9) conclude, controlling $\mathrm{NO}_{x}$ emissions using maximum feasible reductions could substantially decrease future emissions, so the increases we predict on deposition rates (Fig. 1C) may represent upper limits.

\section{Impact on New Primary Production} and the Biological Pump

Present global open ocean primary production is estimated at $\sim 50 \mathrm{Pg} \mathrm{C}_{\text {year }}^{-1}$ (23), equivalent to $\sim 8800 \mathrm{Tg} \mathrm{N}$ year $^{-1}$, assuming Redfield stoichiometry (Table 2 ). Because $\sim 78 \%$ of this production is driven by regeneration of $\mathrm{N}_{\mathrm{r}}$ within surface waters (24) ( $a$ in Fig. 2), it is more relevant to evaluate the impact of AAN deposition on oceanic productivity and biogeochemistry by comparing AAN with global new production, estimated at $\sim 11 \mathrm{Pg} \mathrm{C}$ year $^{-1}(24-26)$. New production ( $b$ in Fig. 2 and Table 2 ) is dominated by nitrate regenerated at depth from sinking organic matter and subsequently returned to the euphotic zone via physical transport ( $b^{\prime}$ in Fig. 2) (27). Over sufficiently large space and time scales
A

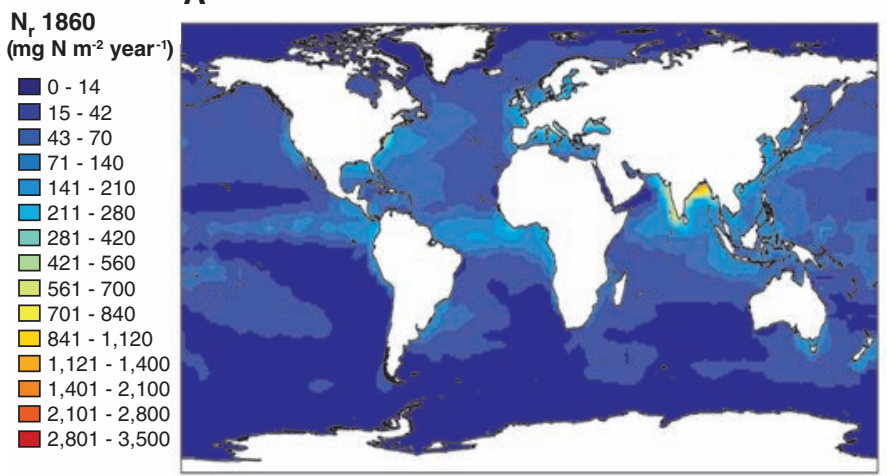

B

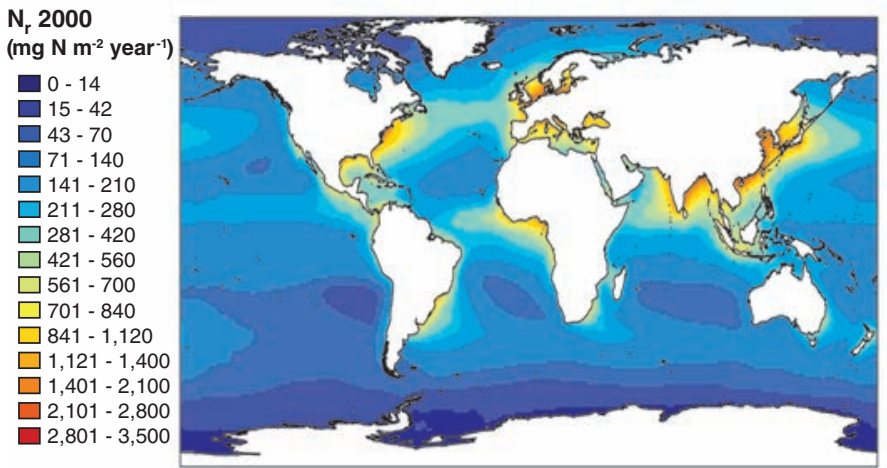

C

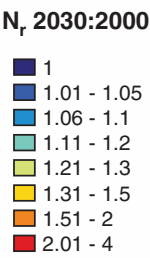

Fig. 1. (A) Total atmospheric reactive nitrogen $\left(\mathrm{N}_{\mathrm{r}}\right)$ deposition in 1860 in $\mathrm{mg} \mathrm{m}^{-2}$ year ${ }^{-1}\left[\mathrm{NH}_{x}\right.$ and $\mathrm{NO}_{y}$ are derived from (3), with the addition of $30 \%$ of the total nitrogen as organic nitrogen]. Total atmospheric $\mathrm{N}_{\mathrm{r}}$ deposition in 1860 was $\sim 20 \mathrm{Tg} \mathrm{N}$ year $^{-1}$, AAN was $\sim 5.7 \mathrm{Tg} \mathrm{N}$ year $^{-1}$. (B) Total atmospheric reactive nitrogen $\left(\mathrm{N}_{\mathrm{r}}\right)$ deposition in 2000 in $\mathrm{mg} \mathrm{m}^{-2}$ year $^{-1}$ [derived from (21) with the addition of $30 \%$ of the total nitrogen as organic nitrogen]. Total atmospheric $\mathrm{N}_{\mathrm{r}}$ deposition in 2000 was $\sim 67 \mathrm{Tg} \mathrm{N}$ year $^{-1}$, AAN was $\sim 54 \mathrm{Tg} \mathrm{N}_{\text {year }}{ }^{-1}$. (C) Ratio of the projected flux of $\mathrm{N}_{\mathrm{r}}$ to the ocean in 2030 to

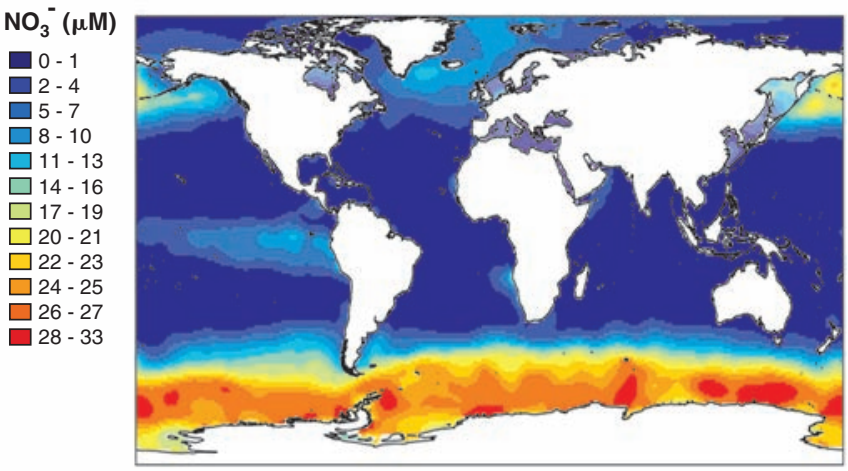

E

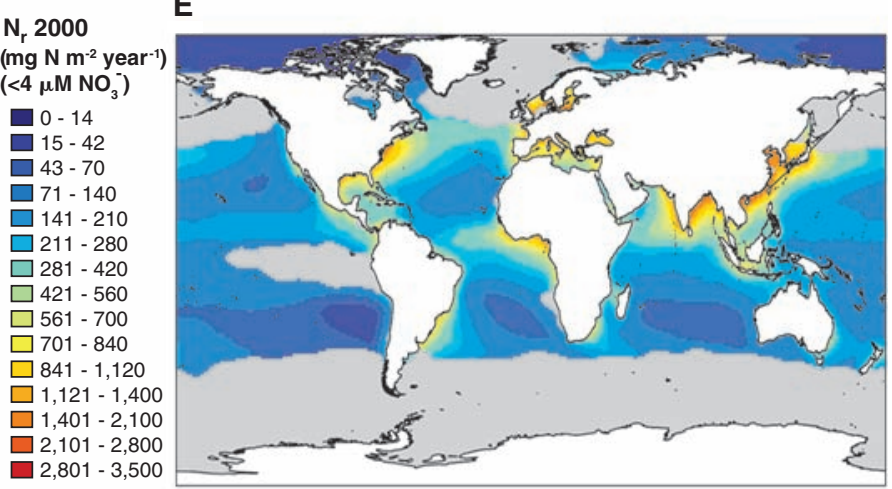

$\mathbf{F}$

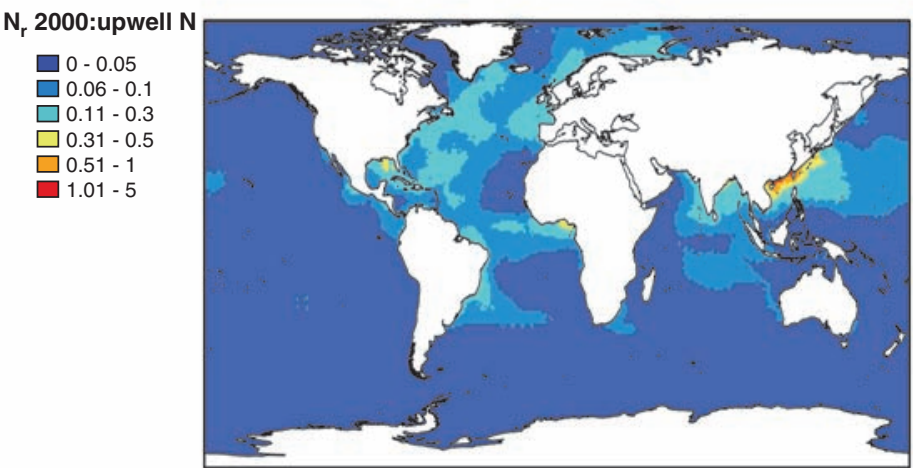

that in 2000. (D) Nitrate concentrations ( $\mu M$ ) in the surface (0 to $1 \mathrm{~m}$ ) waters of the ocean (43). (E) Similar to (B), but with regions where surface nitrate $>4 \mu \mathrm{M}$ has been masked out. Total atmospheric $\mathrm{N}_{\mathrm{r}}$ deposition in 2000 to the nonmasked areas was $\sim 51 \mathrm{Tg} \mathrm{N}_{\text {year }}{ }^{-1}$, AAN was $\sim 41 \mathrm{Tg} \mathrm{N}$ year $^{-1}$. (F) Ratio of total $\mathrm{N}_{\mathrm{r}}$ deposition to dissolved inorganic nitrogen (DIN) supply into the upper $130 \mathrm{~m}$ as diagnosed from a model fitted to oceanic tracer observations (44). To reduce noise, computation of the ratio has been limited to areas with DIN supply exceeding $0.05 \mathrm{~mol} \mathrm{~m}^{-2}$ year $^{-1}$. 
( 1 to $\sim 1000$ years), nitrate-driven new production is balanced by the biologically mediated export of particulate and dissolved organic matter from the surface layer ( $b^{\prime \prime}$ in Fig. 2). On a similar time scale, this component of new production is almost neutral in terms of carbon assimilation (28) because degradation processes release $\mathrm{N}_{\mathrm{r}}$ and $\mathrm{CO}_{2}$ in stoichiometric amounts equivalent to the initial elemental composition of the organic matter. In the absence of denitrification and other fixed nitrogen losses in the ocean interior, nitrate-based new production can be considered a closed loop within which the biologically mediated carbon export $\left(b^{\prime \prime}\right)$ is balanced by a return flux of dissolved inorganic carbon $\left(b^{\prime}\right)$, resulting in near-zero net air-sea $\mathrm{CO}_{2}$ exchange.

Only external (to the ocean) sources of $\mathrm{N}_{\mathrm{r}}$ that reach the surface mixed layer can affect the steady-state balance of the biologically mediated flux of $\mathrm{CO}_{2}$ across the air-sea interface. The two known open ocean sources of external $\mathrm{N}_{\mathrm{r}}$ are biological $\mathrm{N}_{2}$ fixation ( $c$ in Fig. 2) and atmospheric deposition $(d)$. Together these contribute a net oceanic input of $\mathrm{N}_{\mathrm{r}}$ that can support "completely new production" and hence influence global oceanic $\mathrm{N}_{\mathrm{r}}$ and the net atmosphere-to-ocean exchange of $\mathrm{CO}_{2}$, assuming an adequate supply of other nutrients $(\mathrm{P}, \mathrm{Fe})$. Although $\mathrm{N}_{2}$ fixation must have dominated the flux of external new nitrogen in the preindustrial world, atmospheric $\mathrm{N}_{\mathrm{r}}$ deposition is now approaching $\mathrm{N}_{2}$ fixation as a result of the

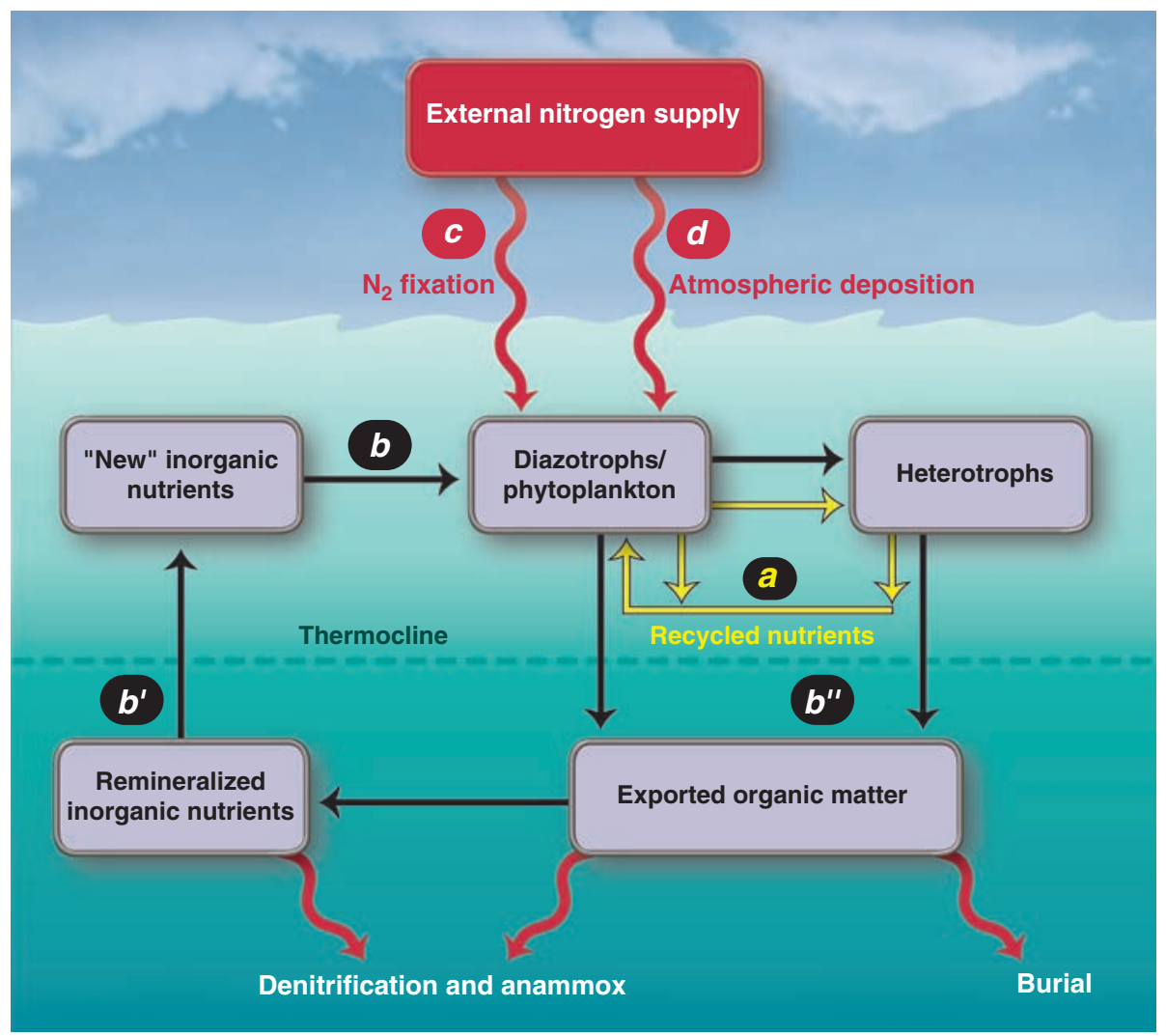

Fig. 2. Schematic of the processes supplying nutrients for surface primary production. See text for detailed description. dramatic increase in the anthropogenic component (Table 2).

Can this atmospheric $\mathrm{N}_{\mathrm{r}}$ deposition be rapidly assimilated into primary production? It will impact the biogeochemistry of oceanic areas that are either perennially or seasonally depleted in surface nitrate, but will have little effect in highnutrient, low-chlorophyll (HNLC) regions where the concentration of surface nitrate is always high. Comparing surface nitrate concentrations (Fig. 1D) and total $\mathrm{N}_{\mathrm{r}}$ deposition (Fig. 1B) shows the relatively small overlap between high $\mathrm{N}_{\mathrm{r}}$ deposition and significant surface nitrate concentrations. In regions where surface nitrate is seasonally depleted (i.e., where productivity is nitrogen limited), atmospheric deposition would likely be assimilated during the year. Although $\mathrm{N}_{\mathrm{r}}$ generally is seasonally exhausted in regions where mean annual nitrate is $<7 \mu \mathrm{M}$, a more conservative value of $<4 \mu \mathrm{M}$ is used to calculate the distribution of the atmospheric $\mathrm{N}_{\mathrm{r}}$ deposition in present-day nitrogen-depleted waters (Fig. 1E). The calculated global $\mathrm{N}_{\mathrm{r}}$ deposition to regions with mean nitrate $<4 \mu \mathrm{M}$ is $\sim 51 \mathrm{Tg} \mathrm{N}$ year $^{-1}$, or $\sim 76 \%$ of the total atmospheric $\mathrm{N}_{\mathrm{r}}$ deposited in the ocean, compared to $\sim 56 \mathrm{Tg} \mathrm{N}^{\mathrm{N}}$ year $^{-1}(\sim 84 \%$ of total deposition) if $<7 \mu \mathrm{M}$ is used as a threshold. Corresponding values for AAN are $\sim 41$ and $\sim 45 \mathrm{Tg} \mathrm{N}$ year $^{-1}$. Using the areas delineated by the $<4 \mu \mathrm{M}$ and $<7 \mu \mathrm{M}$ nitrate concentrations above, we calculate that $\sim 67$ to $75 \%$ of oceanic by AAN deposition (14) assumed a different nitrogen-limited area, lower atmospheric fluxes, and the assumption that $\mathrm{N}$ enhancement will result in the replacement of diazotrophs by other phytoplankton.

Increased new production due to AAN fertilization coincides with the anthropogenic perturbation of the global carbon cycle and penetration of anthropogenic carbon in the ocean. The current anthropogenic $\mathrm{CO}_{2}$ uptake by the ocean is $\sim 2.2 \pm 0.5 \mathrm{Pg} \mathrm{C}_{\text {year }}{ }^{-1}$ (30), primarily attributed to physical-chemical processes (the "solubility pump"). Assuming that new production draws down atmospheric $\mathrm{CO}_{2}$ according to Redfieldian stoichiometry, up to $\sim 10 \%$ of the present anthropogenic carbon uptake could be attributed to anthropogenic nitrogen fertilization This potentially significant enhancement of the oceanic uptake of anthropogenic carbon indicates the need to incorporate this factor in future Earth system assessments and models, as has already been done for terrestrial ecosystems (31). This estimate may be lower if the dissolved organic carbon or particulate organic carbon produced is regenerated at shallow depths (32). The efficiency and longevity of this anthropogenic nitrogen fertilization effect depend on temporal uncoupling of the new $\mathrm{N}_{\mathrm{r}}$ inputs $\left(\mathrm{N}_{2}\right.$ fixation and atmospheric deposition) from $\mathrm{N}_{\mathrm{r}}$ removal (e.g., denitrification/anammox and burial). Assuming that all other essential nutrients are in adequate supply, it will be operational as long as the 
increase in new $\mathrm{N}_{\mathrm{r}}$ (and associated additional $\mathrm{CO}_{2}$ uptake) is not balanced by increased regeneration of $\mathrm{N}_{2}$ and $\mathrm{CO}_{2}$ and release at the ocean-air interface. Eventually, if AAN deposition levels off, the ocean may reach a new steady state with respect to nitrogen gains and losses that is neutral with respect to $\mathrm{CO}_{2}$ uptake over time scales similar to the oceanic $\mathrm{N}$ residence time ( 1000 years).

The future impact of AAN on productivity must be evaluated in the context of predicted changes in productivity caused by other variables. For instance, elevated concentrations of atmospheric $\mathrm{CO}_{2}$ may have resulted in excess carbon consumption and export because of shifting C:N stoichiometry (33), and it is unclear whether projected AAN and high $\mathrm{CO}_{2}$ concentrations have synergy or compensate. El NiñoSouthern Oscillation (ENSO)-induced higher water temperatures and the associated increased stratification in low-latitude oceans may have reduced productivity by $60 \%$ in some regions (34). Thus, in a warmer climate, decreases in productivity due to restricted injection of nutrientrich deep water would only accentuate the importance of AAN contributions to new production in low-latitude oligotrophic oceanic areas where AAN already has a strong effect. Assuming that all $\mathrm{N}_{\mathrm{r}}$ deposition is assimilated into primary production, this $\mathrm{N}_{\mathrm{r}}$-driven new production could contribute as much as $20 \%$ of the total new (or export) production in such regions where upwelling is limited, e.g., the North Atlantic gyre (Fig. 1F). The contribution of $\mathrm{N}_{\mathrm{r}}$ deposition to new production is higher in the Atlantic than the Pacific and can reach magnitudes comparable to export production along some continental areas.

Table 1. Atmospheric nitrogen emissions and deposition to the ocean. Assumed uncertainties - emissions: 1860: $\pm 50 \%$; 2000: $\mathrm{NO}_{x} \pm 30 \%, \mathrm{NH}_{3} \pm 50 \%$; 2030: see text and (20). Deposition: 1860: $\pm 50 \% ; 2000$ : $\mathrm{NO}_{y} / \mathrm{NH}_{x} \pm 40 \%$, organic $\mathrm{N} \pm 50 \%$; 2030: see text and (20).

\begin{tabular}{|c|c|c|c|}
\hline & $\begin{array}{c}1860^{*} \\
\left(\operatorname{Tg~}^{\text {N year }}{ }^{-1}\right)\end{array}$ & $\begin{array}{c}2000^{\dagger} \\
\left(\operatorname{Tg~N~year}^{-1}\right)\end{array}$ & $\begin{array}{c}2030^{\dagger} \\
\left(\operatorname{Tg~N} \text { year }^{-1}\right)\end{array}$ \\
\hline \multicolumn{4}{|c|}{ Emission to the atmosphere } \\
\hline Total $\mathrm{NO}_{x}$ & $13(7-20)$ & $52(36-68)$ & $54^{\ddagger}$ \\
\hline Anthropogenic $\mathrm{NO}_{x}$ & $2.6(1.3-4)$ & $38(27-49)$ & 43 \\
\hline Total $\mathrm{NH}_{3}$ & $21(11-32)$ & $64(32-96)$ & $78^{\ddagger}$ \\
\hline Anthropogenic $\mathrm{NH}_{3}$ & $7.4(3.7-11)$ & $53(27-80)$ & 70 \\
\hline Total atmospheric $\mathrm{N}$ emissions & $34(18-52)$ & $116(68-164)$ & 132 \\
\hline Total anthropogenic $\mathrm{N}_{\mathrm{r}}(\mathrm{AAN})$ & $10(5-15)$ & $91(54-129)$ & 113 \\
\hline \multicolumn{4}{|c|}{ Deposition to the ocean } \\
\hline Total $\mathrm{NO}_{y}$ & $6.2(3.1-9.3)$ & $23(14-32)$ & 25 \\
\hline Anthropogenic $\mathrm{NO}_{y}$ & $1.2(0.6-1.8)$ & $17(10-24)$ & 18 \\
\hline Total $\mathrm{NH}_{x}$ & $8(4-12)$ & $24(14-34)$ & 29 \\
\hline Anthropogenic $\mathrm{NH}_{x}$ & $2.4(1.2-3.6)$ & $21(13-29)$ & 25 \\
\hline Total organic $\mathrm{N}_{\mathrm{r}}$ & $6.1(3.0-9.1)$ & $20(10-30)$ & 23 \\
\hline Anthropogenic organic $N_{r}$ & $2.1(1.0-3.1)$ & $16(8-24)$ & 19 \\
\hline Total $\mathrm{N}_{\mathrm{r}}$ deposition & $20(10-30)$ & $67(38-96)$ & 77 \\
\hline Total anthropogenic $\mathrm{N}_{\mathrm{r}}(\mathrm{AAN})$ & $5.7(2.8-8.5)$ & $54(31-77)$ & 62 \\
\hline
\end{tabular}

*From (3). †Derived from (21); see text and (26). $\ddagger \mathrm{NO}_{x}$ and $\mathrm{NH}_{3}$ based on $\sim 80 \%$ and $\sim 90 \%$ anthropogenic, respectively [from (3)].

Table 2. Atmospheric nitrogen deposition to the ocean in 2000 and its impact on productivity. Globalscale estimates of total primary production (23); new production (24-26); $\mathrm{N}_{2}$ fixation $(2,6-8)$. Most letters in italics refer to flux pathways in Fig. 2.

\begin{tabular}{|c|c|c|}
\hline & $\begin{array}{l}\text { Global ocean nitrogen } \\
\left(\mathrm{Tg} \mathrm{N} \text { year }^{-1}\right)\end{array}$ & $\begin{array}{l}\text { Resultant global } \\
\text { ocean productivity } \\
\left(\mathrm{PgC} \text { year }^{-1}\right)\end{array}$ \\
\hline Total primary production $(a+b+c+d)$ & $\sim 8800(7000-10,500)$ & $\sim 50(40-60)$ \\
\hline New production (NP) $(b)$ & 1900 (1400-2600) & $\sim 11(8-15)$ \\
\hline Marine $\mathrm{N}_{2}$ fixation $(c)$ & $\sim 100(60-200)$ & $\sim 0.57(0.3-1.1)$ \\
\hline Total net $\mathrm{N}_{\mathrm{r}}$ deposition $(d)\left(\mathrm{NO}_{y}+\mathrm{NH}_{x}+\mathrm{Org} . \mathrm{N}_{\mathrm{r}}\right.$ & $\sim 67(38-96)$ & $\sim 0.38(0.22-0.55)$ \\
\hline Total external nitrogen supply $(c+d)$ & 167 (98-296) & $\sim 0.95(0.56-1.7)$ \\
\hline Anthropogenic $\mathrm{N}_{\mathrm{r}}$ deposition (AAN) (e) & $\sim 54(31-77)$ & $\sim 0.31(0.18-0.44)$ \\
\hline Marine $\mathrm{N}_{2}$ fixation as $\% \mathrm{NP} \mathrm{N}_{\mathrm{r}}$ & $=c / b$ & $\sim 5.3 \%(2.3-14.3 \%)$ \\
\hline Total $\mathrm{N}_{\mathrm{r}}$ deposition as $\%$ NP $\mathrm{N}_{\mathrm{r}}$ & $=d / b$ & $\sim 3.5 \%(1.5-6.9 \%)$ \\
\hline AAN as $\% N P N_{r}$ & $=e / b$ & $\sim 2.8 \%(1.2-5.5 \%)$ \\
\hline Total $\mathrm{N}_{\mathrm{r}}$ deposition as $\%$ external $\mathrm{N}$ supply & $=d /(c+d)$ & $\sim 40 \%(13-98 \%)$ \\
\hline AAN as $\%$ external $\mathrm{N}$ supply & $=e /(c+d)$ & $\sim 32 \%(10-79 \%)$ \\
\hline
\end{tabular}

On the basis of future scenarios for anthropogenic emissions, AAN contribution to primary production could approach current estimates of global $\mathrm{N}_{2}$ fixation by 2030 . Fertilization of the surface layer by atmospheric deposition, primarily AAN, could even lead to a decrease in $\mathrm{N}_{2}$ fixation due to biological competition (14). However, atmospheric $\mathrm{N}_{\mathrm{r}}$ deposition has a very small effect on the surface seawater ambient $\mathrm{N}_{\mathrm{r}}$ concentrations, too little to inhibit nitrogenase activity directly [e.g., we estimate that an extremely rare and large atmospheric deposition event distributed over a 25-m mixed-layer depth could increase the $\mathrm{N}_{\mathrm{r}}$ concentration by only $\sim 45 \mathrm{nM}$ (35), which is too small to suppress $\mathrm{N}_{2}$ fixation (36)]. Atmospheric $\mathrm{N}_{\mathrm{r}}$ deposition more likely represents a long-term low-level fertilization of the ocean that has consequences for the natural biogeochemical cycles of nitrogen and carbon and their ongoing anthropogenic perturbations. Biological evidence suggests that phytoplankton communities in oceanic gyres are presently nitrogen limited (1). Atmospheric $\mathrm{N}_{\mathrm{r}}$ deposition, in the absence of significant atmospheric deposition of phosphorus, may exacerbate phosphorus limitation of $\mathrm{N}_{2}$ fixation. The long-term effect of AAN deposition on $\mathrm{N}_{2}$ fixation depends on whether $\mathrm{P}$ or Fe limits $\mathrm{N}_{2}$ fixation and on the supply ratio of bioavailable $\mathrm{N}: \mathrm{P}: \mathrm{Fe}$ derived from atmospheric deposition (37). Atmospheric deposition of phosphorus is much less perturbed by human activity than $\mathrm{N}_{\mathrm{r}}(13,37)$. Hence, the overall impact of atmospheric deposition is likely to be a shift in the N/P balance of surface waters. Some marine diazotrophs can exploit dissolved organic phosphorus pools and may obtain an adequate $\mathrm{P}$ supply by degrading compounds such as phosphonates (38).

Changes in species composition and productivity can lead to changes in the export of nitrogen and carbon to deep ocean water, resulting in a shift of deep ocean N/P ratios away from Redfield stoichiometry, which could then influence the chemistry of upwelled waters remote from the loci of atmospheric depositions. Remineralization of this extra organic carbon flux in deep waters may reduce the deepwater $\mathrm{O}_{2}$ concentration, and the resultant microbial $\mathrm{N}_{2}$ production will act to restore the N/P ratio toward the Redfield value, as suggested to have happened in the past (39). (See Supporting Online Material, including fig. S2).

\section{Impact on $\mathrm{N}_{2} \mathrm{O}$ Emissions from the Ocean}

Another important issue is whether increasing atmospheric $\mathrm{N}_{\mathrm{r}}$ inputs to the ocean can alter marine emissions of nitrous oxide $\left(\mathrm{N}_{2} \mathrm{O}\right)$, a major greenhouse gas. Estimates of global sea-to-air $\mathrm{N}_{2} \mathrm{O}$ fluxes vary considerably. Two recent estimates are the Intergovernmental Panel on Climate Change (IPCC) assessment (30) (3.8 Tg N year ${ }^{-1}$ as $\mathrm{N}_{2} \mathrm{O}$ ) and the calculation by Bange of the mean from data in (40) $\left(6.2 \mathrm{Tg} \mathrm{N}_{\text {year }}{ }^{-1}\right)$. Using the mean $\left(5.0 \mathrm{Tg} \mathrm{N}\right.$ year $\left.^{-1}\right)$ and the range of these two estimates, and assuming that the nitrogen in 
this "recent" $\mathrm{N}_{2} \mathrm{O}$ flux originally entered the oceans from $\mathrm{N}_{2}$ fixation (100 $\mathrm{Tg} \mathrm{N}$ year ${ }^{-1}$ ) and atmospheric deposition $\left(67 \mathrm{Tg} \mathrm{N}_{\mathrm{Near}}{ }^{-1}\right)$, then the emission of $5.0 \mathrm{Tg} \mathrm{N}$ year ${ }^{-1}$ as $\mathrm{N}_{2} \mathrm{O}$ results from nitrification and denitrification of part of this $167 \mathrm{Tg} \mathrm{N}$ year $^{-1}$ entering the surface ocean. This assumes that $\mathrm{N}_{2} \mathrm{O}$ production in the near-surface ocean is at steady state and there are no significant time lags between atmospheric input and $\mathrm{N}_{2} \mathrm{O}$ formation. Normalizing the $\mathrm{N}_{2} \mathrm{O}$ flux to the atmosphere by the "completely new" nitrogen input (5.0:167) can then be used to estimate that AAN deposition has resulted in the production of up to $\sim 1.6 \mathrm{Tg} \mathrm{N}_{2} \mathrm{O}-\mathrm{N}$ year ${ }^{-1}$, or about a third of total oceanic $\mathrm{N}_{2} \mathrm{O}$ emissions. This approach suggests that in 1860 , only $\sim 0.2 \mathrm{Tg} \mathrm{N}$ year $^{-1}$ $(\sim 5 \%)$ of the sea-to-air flux of $\mathrm{N}_{2} \mathrm{O}$ was driven by atmospheric anthropogenic inputs, assuming simplistically that $\mathrm{N}_{2} \mathrm{O}$ production is linearly related to $\mathrm{N}$ supply. [We use linear scaling due to the lack of experimental and modeling studies that address the spatial and nonlinear response of $\mathrm{N}_{2} \mathrm{O}$ emissions to $\mathrm{N}$ deposition, although important regional variations are likely (41).] This suggests that from 1860 to the present, the increase in AAN has led to nearly an order of magnitude increase in anthropogenic $\mathrm{N}_{2} \mathrm{O}$ emission from the oceans. Calculations and estimates of increases for 2030 are in table S1.

While oceanic AAN deposition may result in increased $\mathrm{N}_{2} \mathrm{O}$ emissions, increasing radiative forcing, AAN also increases primary production (up to $\sim 0.3 \mathrm{Pg} \mathrm{C}$ year $^{-1}$ detailed above) and export production to the deep ocean, removing $\mathrm{CO}_{2}$ from the atmosphere and therefore decreasing radiative forcing. With a Global Warming Potential of 298 for $\mathrm{N}_{2} \mathrm{O}$ (42), the net balance suggests that about two-thirds of the decrease in radiative forcing from $\mathrm{CO}_{2}$ uptake could be offset by the increase due to $\mathrm{N}_{2} \mathrm{O}$ emissions. The uncertainty in our estimates is considerable; however, the estimates suggest the potential importance of AAN to $\mathrm{N}_{2} \mathrm{O}$ emissions and therefore the need for future research in regions such as oceanic Oxygen Minimum Zones (OMZs), which, although small in area, are potentially important for $\mathrm{N}_{2} \mathrm{O}$ emissions. The future role of OMZs will be influenced not only by AAN but also by climate and other global changes.

\section{Conclusions}

This analysis emphasizes the potential importance of the growing quantity of atmospheric reactive (fixed) nitrogen that enters the open ocean as a result of human activities and its impact on the present marine nitrogen cycle. Considering the increasing demand for energy and fertilizers, the emissions of AAN are expected to grow over the coming decades. Atmospheric deposition of anthropogenic nitrogen to the ocean may account for up to $\sim 3 \%$ of the annual new oceanic primary productivity, but about a third of the primary productivity generated as a result of the external input of nitrogen to the ocean. The input of AAN is approaching that of
$\mathrm{N}_{2}$ fixation as a source of marine reactive nitrogen. Although local AAN deposition seems unlikely to alter significantly local phytoplankton species composition, the phytoplankton community could be affected by the slow long-term fertilization of surface waters by AAN. Moreover, AAN inputs to the ocean have potentially important climatic implications. Up to about a tenth of the anthropogenic atmospheric carbon uptake by the ocean $\left(\mathrm{as}_{2}\right)$ may result from this fertilization. In addition, $\mathrm{AAN}$ inputs may stimulate $\mathrm{N}_{2} \mathrm{O}$ emissions, with possibly about two-thirds of the decrease in radiative forcing from increased $\mathrm{CO}_{2}$ uptake by the ocean being offset by the increase in radiative forcing from increased $\mathrm{N}_{2} \mathrm{O}$ emissions.

There is clearly much we do not know about the extent and time scale of the impacts of AAN deposition on the oceans and the feedbacks to the climate system. The issues are complex and interactive, and they must be considered in climate scenarios. Areas of particular importance include understanding more fully the sources, chemical speciation, reactivity, and availability of atmospheric organic nitrogen; developing more realistic models of $\mathrm{N}_{\mathrm{r}}$ deposition to the ocean, coupled with measuring $\mathrm{N}_{\mathrm{r}}$ deposition over extended periods of time in open ocean regions; understanding the relationships between, and impacts of, the atmospheric deposition of bioavailable N, P, and $\mathrm{Fe}$; and understanding the mechanisms and time scales involved in the oceanic response to $\mathrm{N}_{\mathrm{r}}$ deposition, coupled with a new generation of Earth system models that take into account longterm low-level nitrogen fertilization of the ocean and evaluate the effect on $\mathrm{N}_{2} \mathrm{O}$ emissions and the duration of the enhanced (anthropogenic) $\mathrm{CO}_{2}$ uptake.

\section{References and Notes}

1. M. M. Mills, C. Ridame, M. Davey, J. La Roche, R. J. Geider, Nature 429, 292 (2004).

2. N. Gruber, J. Sarmiento, in The Sea: Biological-Physical Interactions, A. R. Robinson, J. F. McCarthy,

B. Rothschild, Eds. (Wiley, New York, 2002), vol. 12, pp. 337-399.

3. J. N. Galloway et al., Biogeochemistry 35, 3 (1996).

4. S. P. Seitzinger, J. A. Harrison, E. Dumont,

A. H. W. Beusen, A. F. Bouwman, Global Biogeochem. Cycles 19, GB4S01 (2005).

5. S. Seitzinger et al., Ecol. Appl. 16, 2064 (2006).

6. C. Mahaffey, A. F. Michaels, D. G. Capone, Am. J. Sci. 305, 546 (2005).

7. J. K. Moore, S. C. Doney, K. Lindsay, N. Mahowald, A. F. Michaels, Tellus 58B, 560 (2006).

8. C. Deutsch, J. L. Sarmiento, D. M. Sigman, N. Gruber, J. P. Dunne, Nature 445, 163 (2007).

9. J. N. Galloway et al., Science 320, 889 (2008).

10. R. A. Duce et al., Global Biogeochem. Cycles 5, 193 (1991).

11. J. M. Prospero et al., Biogeochemistry 35, 27 (1996).

12. C. M. Duarte et al., J. Geophys. Res. 111, G04006 (2006).

13. T. Jickells, Biogeosciences 3, 271 (2006).

14. A. Krishnamurthy, ]. K. Moore, C. S. Zender, C. Luo, J. Geophys. Res. 112, G02019 (2007).

15. H. W. Paerl, Nature 315, 747 (1985).

16. S. C. Doney et al., Proc. Natl. Acad. Sci. U.S.A. 104, 14580 (2007)

17. S. E. Cornell, T. D. Jickells, J. N. Cape, A. P. Rowland, R. A. Duce, Atmos. Environ. 37, 2173 (2003).

18. K. A. Mace, R. A. Duce, N. W. Tindale, J. Geophys. Res. 108, 4338 (2003)

19. T. Nakamura, H. Ogawa, D. K. Maripi, M. Uematsu, Atmos. Environ. 40, 7259 (2006).
20. If the assumption that in 1860 the relationship between organic and inorganic $\mathrm{N}$ in deposition was the same as today, i.e., that organic nitrogen is $\sim 30 \%$ of the total $N_{r}$, is in error, then it is likely that both the total and the anthropogenic nitrogen deposition in 1860 would have been less than indicated in Table 1.

21. F. Dentener et al., Global Biogeochem. Cycles 20, GB4003 (2006)

22. The deposition estimates for 2030 are based on the $\mathbf{S 2}$ simulation of $\mathrm{NO}_{x}$ and $\mathrm{NH}_{3}$ emissions to the atmosphere presented in (21), which uses an IIASA CLE 2030 current emission regulation scenario, termed "likely" in that paper. We estimate that the atmospheric emission and deposition values shown in Table 1 for 2030 have uncertainties of $\sim 40$ to $50 \%$. Dentener et al. (21) also discuss results using the "optimistic" IIASA Maximum Feasible Reduction (MFR) scenario and the "pessimistic" IPCC SRES A2 scenario. Depending on the regional development path of $\mathrm{N}_{\mathrm{r}}$ emissions, $\mathrm{N}_{\mathrm{r}}$ depositions may be lower by 10 to $70 \%$ (MFR) or higher by 30 to $200 \%$.

23. M. E. Carr et al., Deep-Sea Res. Part I/ 53, 741 (2006).

24. E. A. Laws, P. G. Falkowski, W. O. Smith, H. Ducklow, ]. J. McCarthy, Global Biogeochem. Cycles 14, 1231 (2000).

25. A. Oschlies, Deep-Sea Res. Part // 48, 2173 (2001).

26. H. W. Ducklow, Rev. Geophys. 33, 1271 (1995)

27. R. C. Dugdale, ]. J. Goering, Limnol. Oceanogr. 12, 196 (1967).

28. W. S. Broecker, Global Biogeochem. Cycles 5, 191 (1991).

29. J. L. Sarmiento, N. Gruber, M. A. Brzezinski, ]. P. Dunne, Nature 427, 56 (2004).

30. K. Denman et al., in Climate Change 2007: The Physical Science Basis, S. Solomon et al., Eds. (Cambridge Univ. Press, Cambridge, 2007), pp. 544-547.

31. F. Magnani et al., Nature 447, 849 (2007).

32. A. Gnanadesikan, J. L. Sarmiento, R. D. Slater, Global Biogeochem. Cycles 17, 1050 (2003).

33. U. Riebesell et al., Nature 450, 545 (2007).

34. M. J. Behrenfeld et al., Nature 444, 752 (2006).

35. A. F. Michaels, D. A. Siegel, R. J. Johnson, A. H. Knap, J. N. Galloway, Global Biogeochem. Cycles 7, 339 (1993).

36. C. M. Holl, ]. P. Montoya, J. Phycol. 41, 1178 (2005).

37. A. R. Baker, S. D. Kelly, K. F. Biswas, M. Witt, T. D. Jickells, Geophys. Res. Lett. 30, 2296 (2003).

38. S. T. Dyhrman et al., Nature 439, 68 (2006).

39. R. S. Ganeshram, T. F. Pedersen, S. E. Calvert, G. W. McNeill, M. R. Fontugne, Paleoceanography 15, 361 (2000).

40. H. W. Bange, Atmos. Environ. 40, 198 (2006).

41. X. Jin, N. Gruber, Geophys. Res. Lett. 30, GL18458 (2003).

42. S. Solomon et al., in Climate Change 2007: The Physical Science Basis, S. Solomon et al., Eds. (Cambridge Univ. Press, Cambridge, 2007).

43. M. E. Conkright et al., World Ocean Atlas 2001, vol. 4, Nutrients, S. Levitus, Ed., NOAA Atlas NESDros. Inf. Serv. 52 (U.S. Government Printing Office, Washington, DC, 2002).

44. R. Schlitzer, J. Phys. Oceanogr. 37, 259 (2007)

45. We acknowledge the leadership of the Surface Ocean-Lower Atmosphere Study (SOLAS) project (www.solas-int.org) and the International Nitrogen Initiative (www.initrogen.org) of SCOPE and the International Geosphere-Biosphere Programme (IGBP; www.igbp.kva.se) for conceiving this synthesis. We thank the Scientific Committee on Oceanic Research, IGBP, the U.S. National Oceanic and Atmospheric Administration, and the European Science Foundation for partial support of the work. We thank ]. Hare of the SOLAS International Project Office for help in organizing the workshop and E. Breviere of that office for help in making the Nitrogen Workshop in Norwich, UK, a success. We acknowledge two anonymous reviewers for constructive feedback.

\section{Supporting Online Material}

www.sciencemag.org/cgi/content/full/320/5878/893/DC1 SOM Text

Figs. S1 and S2

Table S1

References

10.1126/science.1150369 


\section{Science}

\section{Impacts of Atmospheric Anthropogenic Nitrogen on the Open Ocean}

R. A. Duce, J. LaRoche, K. Altieri, K. R. Arrigo, A. R. Baker, D. G. Capone, S. Cornell, F. Dentener, J. Galloway, R. S. Ganeshram, R. J. Geider, T. Jickells, M. M. Kuypers, R. Langlois, P. S. Liss, S. M. Liu, J. J. Middelburg, C. M. Moore, S. Nickovic, A. Oschlies, T. Pedersen, J. Prospero, R. Schlitzer, S. Seitzinger, L. L. Sorensen, M. Uematsu, O. Ulloa, M. Voss, B. Ward and L. Zamora

Science 320 (5878), 893-897.

DOI: $10.1126 /$ science.1150369

ARTICLE TOOLS

SUPPLEMENTARY MATERIALS

RELATED

CONTENT

REFERENCES

PERMISSIONS http://science.sciencemag.org/content/320/5878/893

http://science.sciencemag.org/content/suppl/2008/05/15/320.5878.893.DC1

http://science.sciencemag.org/content/sci/320/5878/889.full

This article cites 39 articles, 3 of which you can access for free http://science.sciencemag.org/content/320/5878/893\#BIBL

http://www.sciencemag.org/help/reprints-and-permissions

Use of this article is subject to the Terms of Service

Science (print ISSN 0036-8075; online ISSN 1095-9203) is published by the American Association for the Advancement of Science, 1200 New York Avenue NW, Washington, DC 20005. The title Science is a registered trademark of AAAS.

American Association for the Advancement of Science 